\title{
ASSESSMENT OF NUTRITIONAL STATUS IN MAJOR PSYCHIATRIC DISORDERS OF A TERTIARY CARE HOSPITAL
}

Subhendu Datta1, Rumi Gayen², Indranil Chakraborty³

${ }_{1}^{1}$ RMO cum Clinical Tutor, Department of Psychiatry, College of Medicine and Sagore Datta Hospital, Kolkata,

West Bengal, India.

${ }^{2}$ Assistant Professor, Department of Biochemistry, College of Medicine and Sagore Datta Hospital, Kolkata, West Bengal, India. 3Professor and HOD, Department of Biochemistry, College of Medicine and Sagore Datta Hospital, Kolkata, West Bengal, India.

ABSTRACT

\section{BACKGROUND}

There was substantial evidence to support the relationship between overweight, obesity and medical conditions, but little was known about their relationships to psychiatric disorders.[1] Clinical observations had suggested possible relationship between obesity and depression.[2] Being overweight or obese and having increased psychiatric symptoms had been explained by some literatures, ${ }^{[3,4]}$ whereas other literatures failed to document direct associations between obesity and depression. ${ }^{[5,6]}$

Our aim was to identify relationship between major psychiatric disorders and nutritional status with the help of anthropometry and a few biochemical parameters.

\section{MATERIALS AND METHODS}

It was a cross-sectional study. 67 women and 29 men reporting to the Outpatient Department of Psychiatry, College of Medicine and Sagore Dutta Hospital, a tertiary care centre in West Bengal, India. Patients were diagnosed by the psychiatrist according to International Classification of Diseases-10 (ICD-10) guidelines. Assessment of the nutritional status of the respondents consisted of anthropometric measurements and examination of few biochemical parameters.

\section{RESULTS}

Mean age of men and women was 40.78 yrs. (SD \pm 12.93 ) and 41.28 yrs. (SD \pm 11.93$)$ respectively. Mean Body Mass Index (BMI) of anxiety $(22.33 \pm 3.95)$ and psychotic patients $(21.05 \pm 3.4)$ were normal except mood disorder $(23.17 \pm 4.21)$ patients. Mean concentration of Total Cholesterol (TC) is highest in mood disorder (178.20 \pm 41.12$)$ followed by anxiety (166.26 \pm 26.59$)$ and lowest in psychosis (149.63 \pm 25.86). In mood disorders patient's mean BMI, Body Fat percentage (BF\%), Central Skin Fold Thickness (CSFT) and Peripheral Skin Fold Thickness (PSFT) was higher in women than men and it was statistically significant.

\section{CONCLUSION}

Major psychiatric disorders were common in normal BMI people.

\section{KEY WORDS}

Anthropometry, Nutrition, Major Psychiatric Disorders.

HOW TO CITE THIS ARTICLE: Datta S, Gayen R, Chakraborty I. Assessment of nutritional status in major psychiatric disorders of a tertiary care hospital. J. Evolution Med. Dent. Sci. 2018;7(43):4616-4620, DOI: 10.14260/jemds/2018/1030

\section{BACKGROUND}

It had been a scientific focus of debate for 50 years over whether mood disorders and obesity were related.[7-9] Some studies described increased risk of depression among the obese, others showed decreased risk of depression among the obese, not only that others documented no effect of obesity on risk for depression.[10] Analysis of First National Health and Nutrition Examination Survey (NHANES I) also showed the relative body weight was poorly related to elevated depression score in women than in men.[4] Another study found no relationship between obesity and mental health functioning. [11]

'Financial or Other Competing Interest': None.

Submission 14-09-2018, Peer Review 08-10-2018,

Acceptance 15-10-2018, Published 22-10-2018.

Corresponding Author:

Dr. Rumi Gayen,

Sree Krishna Apartment,

$2^{\text {nd }}$ Floor, Flat No. E-1,

187/1, Bose Para Garia,

Kolkata-700084,

West Bengal, India.

E-mail: drrumi77@gmail.com

DOI: $10.14260 / \mathrm{jemds} / 2018 / 1030$
A study showed that more severely depressed women at baseline had greater subsequent risk to become overweight, but in that study author did not address whether obesity increased risk for depression and they also noted women between 38 - 54 years' age group there was no association of obesity with anxiety, phobias and depression.[12] In contrast, de Wit et al in their meta-analysis of 17 community-based cross-sectional studies confirmed that depression was associated with an increased risk of being obese.[13] $\mathrm{A}$ systemic review and meta-analysis showed longitudinal bidirectional association between depression and obesity.[14] In anxiety disorders its relationship with obesity was modest, inconsistent and inadequate for other psychiatric conditions.[15]

The purpose of this study was to explore the relationship between nutrition and major psychiatric disorders, mainly in psychotic disorders, anxiety disorders and mood disorders. Our hypothesis was that the nutritional status of the individual had little relationship with the major psychiatric disorders. Our aim was to identify relationship of major psychiatric disorders and nutritional status, which had been assessed with the help of anthropometry and a few biochemical parameters. 


\section{MATERIALS AND METHODS}

It was a cross-sectional study. The study was carried out at Outpatient's Department (OPD) of Psychiatry and Department of Biochemistry of College of Medicine and Sagore Dutta Hospital, a tertiary care centre in West Bengal, India. The study group comprised of total 96 psychiatric patients including male and female. Patients were recruited at the Outpatient Department of Psychiatry with their first episode of psychiatric morbidity and were diagnosed by the psychiatrist according to ICD-10 guidelines. Next, they were classified into three different groups: Psychotic disorders $(n=8)$, Anxiety disorders $(n=29)$ and Mood disorders $(n=54)$.

The purpose of the study was explained to the caregiver of patients and written informed consent was obtained thereafter. The study was approved by the Institutional Ethics Committee.

\section{Measures/ Anthropometric Measurements}

Anthropometric measurements of the participants, such as height $(\mathrm{cm})$ was measured using a stadiometer (SECA 213 Stadiometer), weight was measured using a digital weighing machine (SECA $874 \mathrm{U}$ digital scale), biceps, triceps, subscapular and suprailiac skinfold thicknesses were measured using Harpenden Skinfold Caliper (Holtain, UK). All anthropometric evaluations were conducted in accordance with the standard guidelines,[16] three times in each subject and mean values were obtained. All skin fold thicknesses were measured to the nearest of $1 \mathrm{~mm}$ and the mean of three readings was recorded at each site. Central (sum of subscapular and suprailiac) and peripheral skin fold thicknesses (sum of biceps and triceps) were also calculated. The sum of all skin fold thicknesses was used for the calculation of percentage body fat (BF\%) using the standard equation.[17] The equation for the calculation of $B F \%$ from skin fold thicknesses had been validated in Asian Indians. [18] Body Mass Index (BMI) was calculated as weight in kilograms divided by height in meter squared $\left(\mathrm{kg} / \mathrm{m}^{2}\right)$.

The modified classification of BMI for Asian Indian populations was used in this study to define overweight (23$24.99 \mathrm{~kg} / \mathrm{m}^{2}$ ) and obesity (> $25 \mathrm{~kg} / \mathrm{m}^{2}$ ).[19] $\mathrm{BF} \%>25 \%$ in males and $>30 \%$ in females was set as the upper limit.[20]

\section{Biochemical Analysis}

Fasting blood glucose, Triglyceride (TG), Total Cholesterol (TC), High Density Lipoprotein-Cholesterol (HDL-C) and Low Density Lipoprotein-Cholesterol (LDL-C) concentrations were determined with kits by Erba Mannheim XL System Pack, EM 360 Transasia Autoanalyzer (Germany), in the Department of Biochemistry at College of Medicine and Sagore Dutta Hospital, which is included in Grade "A" category by Erba Mannheim Quality Assurance System (Germany).

\section{Statistics}

Data were entered in a Microsoft Excel spread sheet. All the entries were double entered checking consistency. Descriptive statistics as mean, standard deviation, Independent t-test, ANOVA, Chi-square were applied to examine difference in anthropometric and biochemical parameters between groups. Normal distribution of numerical variables was determined using the Shapiro-Wilk test.

\section{RESULTS}

In this study, total number of men suffering from psychiatric morbidity is 29 and their mean age was 40.78 years (SD \pm 12.93 ). Total women were 67 and their mean age was 41.28 years (SD \pm 11.93 ). All the variables studied follow normal distribution (Table I).

As noted in Table 1, BMI was higher among patients with mood disorders followed by anxiety disorders and psychosis. Similarly, Total Cholesterol (TC), High Density Lipoprotein-C (HDL-C) and Low Density Lipoprotein-C (LDL-C) was highest among patients with mood disorders followed by anxiety disorder and lowest in psychotic patients, but difference was not significant $(\mathrm{p}>0.05)$. Although, triglyceride level was highest among patients with mood disorders, lowest was noted among patients with anxiety disorders.

As revealed in Table 2, the proportion of patients suffering from mood disorders and anxiety disorders were significantly higher among women than the men in the sample.

\begin{tabular}{|c|c|c|c|c|}
\hline Variables & $\begin{array}{c}\text { Psychotic } \\
\text { Disorders } \\
(n=8) \\
\text { (Mean } \pm \\
\text { SD) }\end{array}$ & $\begin{array}{c}\text { Mood } \\
\text { Disorders } \\
(n=54) \\
\text { (Mean } \pm \\
\text { SD) }\end{array}$ & $\begin{array}{c}\text { Anxiety } \\
\text { Disorders } \\
\text { (n= 34) } \\
\text { (Mean } \pm \\
\text { SD) }\end{array}$ & $\begin{array}{c}F \text { test } \\
\text { (P value) }\end{array}$ \\
\hline BMI & $\begin{array}{c}21.05 \pm \\
3.40 \\
\end{array}$ & $\begin{array}{c}23.17 \pm \\
4.21 \\
\end{array}$ & $\begin{array}{c}22.43 \pm \\
3.95 \\
\end{array}$ & $\begin{array}{c}1.085 \\
(0.342) \\
\end{array}$ \\
\hline $\mathrm{TC}(\mathrm{mg} / \mathrm{dL})$ & $\begin{array}{c}149.63 \pm \\
25.86\end{array}$ & $\begin{array}{c}178.20 \pm \\
41.12\end{array}$ & $\begin{array}{c}166.26 \pm \\
26.59 \\
\end{array}$ & $\begin{array}{c}2.81 \\
(0.066) \\
\end{array}$ \\
\hline $\begin{array}{c}\text { LDL-C } \\
(\mathrm{mg} / \mathrm{dL})\end{array}$ & $\begin{array}{c}83.96 \pm \\
17.87 \\
\end{array}$ & $\begin{array}{c}106.93 \pm \\
28.5\end{array}$ & $\begin{array}{c}99.62 \pm \\
21.02 \\
\end{array}$ & $\begin{array}{c}2.954 \\
(0.057) \\
\end{array}$ \\
\hline $\begin{array}{c}\text { HDL-C } \\
\text { (mg/dL) }\end{array}$ & $\begin{array}{l}46 \pm \\
9.61\end{array}$ & $\begin{array}{c}51.58 \pm \\
18.38\end{array}$ & $\begin{array}{c}49.07 \pm \\
11.27\end{array}$ & $\begin{array}{c}0.581 \\
(0.056)\end{array}$ \\
\hline $\mathrm{TG}(\mathrm{mg} / \mathrm{dL})$ & $\begin{array}{c}110.21 \pm \\
38.69\end{array}$ & $\begin{array}{c}119.41 \pm \\
59.1\end{array}$ & $\begin{array}{c}104.09 \pm \\
45.15\end{array}$ & $\begin{array}{c}0.856 \\
(0.428)\end{array}$ \\
\hline
\end{tabular}

Table 1. Distribution of Anthropometric and Biochemical Parameters among Patients of Psychotic, Anxiety and Mood Disorder Patients

SD: Standard Deviation.

\begin{tabular}{|c|c|c|c|}
\hline \multirow{2}{*}{$\begin{array}{c}\text { Types of } \\
\text { Psychiatric } \\
\text { Diseases }\end{array}$} & \multicolumn{2}{|c|}{ Cases } & \multirow{2}{*}{$\begin{array}{c}\text { Chi-Square } \\
\text { (P value) }\end{array}$} \\
\cline { 2 - 3 } & Male n (\%) & $\begin{array}{c}\text { Female n } \\
\text { (\%) }\end{array}$ & \\
\hline $\begin{array}{c}\text { Mood disorders } \\
(54)\end{array}$ & $13(24.1 \%)$ & $41(75.9 \%)$ & \multirow{2}{*}{$\begin{array}{c}9.241 \\
0.026)\end{array}$} \\
\cline { 1 - 2 } $\begin{array}{c}\text { Anxiety disorders } \\
(34)\end{array}$ & $12(35.3 \%)$ & $22(67.7 \%)$ & \\
\hline $\begin{array}{c}\text { Psychotic disorders } \\
(8)\end{array}$ & $04(50 \%)$ & $04(50 \%)$ & \\
\hline
\end{tabular}

Table 2. Distribution of Psychiatric Disorders according to Gender $(n=96)$

As noted in Table 3, the mean values of BMI, BF\%, CSFT (Central Skin Fold Thickness), PSFT (Peripheral Skin Fold Thickness), TC, LDL-C and glucose was higher in women suffering from psychiatric disorders than their male counterparts.

Among patients with mood disorders (Table 4), women were significantly more likely to have higher BMI, BF\%, CSFT and PSFT than male patients $(p<0.05)$. The average serum concentration of TC, LDL-C, HDL-C were also higher among female patients than of male patients, though the difference was not significant $(\mathrm{p}>0.05)$. 


\begin{tabular}{|c|c|c|}
\hline Variables & $\begin{array}{c}\text { Male (n= 29) } \\
\text { Mean } \pm \text { SD }\end{array}$ & $\begin{array}{c}\text { Female (n= 67) } \\
\text { Mean } \pm \text { SD }\end{array}$ \\
\hline BMI & $21.36 \pm 3.32$ & $23.26 \pm 4.26$ \\
\hline Age (yrs.) & $40.78 \pm 12.93$ & $41.28 \pm 11.93$ \\
\hline BF\% & $22.4 \pm 7.78$ & $33.48 \pm 6.7$ \\
\hline CSFT (cm) & $29.19 \pm 16.29$ & $43.45 \pm 22.16$ \\
\hline PSFT (cm) & $18.25 \pm 9.1$ & $29.61 \pm 12.61$ \\
\hline Glucose (mg/dL) & $98.36 \pm 20.16$ & $105.8 \pm 40.40$ \\
\hline TC (mg/dL) & $163.93 \pm 40.04$ & $175.30 \pm 34.15$ \\
\hline HDL-C (mg/dL) & $44.6 \pm 7.76$ & $52.46 \pm 17.30$ \\
\hline LDL-C (mg/dL) & $99.1 \pm 29.66$ & $103.62 \pm 24.14$ \\
\hline TG (mg/dL) & $124.27 \pm 61.65$ & $109.58 \pm 52.14$ \\
\hline Table 3. Distribution of Anthropometric and Blood \\
Biochemical Data according to Gender \\
\hline \multicolumn{3}{|c}{} \\
\hline
\end{tabular}

\begin{tabular}{|c|c|c|c|}
\hline Parameters & $\begin{array}{c}\text { Male (n= 13) } \\
\text { Mean } \pm \text { SD }\end{array}$ & $\begin{array}{c}\text { Female (n=40) } \\
\text { Mean } \pm \text { SD }\end{array}$ & P value \\
\hline BMI & $21.16 \pm 3.30$ & $23.82 \pm 4.3$ & 0.046 \\
\hline BF $\%$ & $21.53 \pm 7.72$ & $34.41 \pm 6.61$ & 0.001 \\
\hline CSFT (cm) & $29.08 \pm 14.16$ & $45.98 \pm 22.87$ & 0.01 \\
\hline PSFT (cm) & $17.34 \pm 8.52$ & $31.83 \pm 12.64$ & 0.001 \\
\hline TC (mg/dL) & $168.58 \pm 44.64$ & $181.24 \pm 40.09$ & 0.358 \\
\hline $\begin{array}{c}\text { HDL-C } \\
(\mathrm{mg} / \mathrm{dL})\end{array}$ & $45.08 \pm 9.52$ & $53.63 \pm 20.06$ & 0.162 \\
\hline $\mathrm{LDL}-\mathrm{C}(\mathrm{mg} / \mathrm{dL})$ & $102.92 \pm 31.97$ & $107.49 \pm 27.68$ & 0.633 \\
\hline TG (mg/dL) & $120.08 \pm 61.42$ & $119.19 \pm 59.19$ & 0.964 \\
\hline \multicolumn{4}{|c|}{$\begin{array}{l}\text { Table 4. Distribution of Anthropometric and Blood } \\
\text { Biochemical Data in Patients with Mood Disorders }\end{array}$} \\
\hline
\end{tabular}

\section{DISCUSSION}

Prevalence of metabolic disturbances in schizophrenia and other psychotic disorders was high.[21,22] One study had documented glucose intolerance, hyperinsulinaemia and accumulation of visceral fat already exhibited in newly diagnosed psychotic non-obese patients.[23] Our observation was patients during the first episode of psychosis neither was there abnormal average glucose concentration nor abnormal lipid metabolism, rather all patients had normal BMI.

Though obesity was a pathological state and more strongly associated with biological disharmony and undesired health outcome,[24] but relationship between obesity and psychiatric disorders were still doubtful. Whether depression was predictive of the development of overweight and obesity or overweight and obesity were predictive of the development of depression is a matter of fact to be explored. A meta-analysis confirmed a reciprocal link between depression and obesity. ${ }^{[14]}$ Our observation was average BMI of mood disorder patients were overweight, not obese. This observation was supported by cross-sectional studies, explained modest relationship between overweight or obesity and any mood disorder or major depressive disorder.[8,25,26] A handful literature showed that there were associations between overweight or obesity and any anxiety disorder including specific phobia,[27-29] panic disorder,[30] Generalised Anxiety Disorder (GAD) ${ }^{[31]}$ and social phobia.[32] On the other hand, some literature reported anxiety disorders did not predict development of overweight or obesity at a later stage. Moreover, baseline overweight and obesity did not predict any anxiety disorders during followup.[28,33] Our observation was drug-naïve anxiety disorder patients had their average BMI within the normal intervals.

Our study set a cross-sectional evidence of normal BMI among psychiatric patients and it was seen BMI was higher in mood disorder patients followed by anxiety disorder patients and lowest in psychotic patients. Partitioning of data according to gender revealed males had normal BMI and females were overweight in mood disorders group and females also had high body fat percentage. Epidemiologic data provided evidences that prevalence of obesity in women and men are different with a greater prevalence in women than in men. [24] Females were more prone to experience MDD (Major Depressive Disorder) than their male counterpart.[34] The actual mechanisms of how women and men exhibited different association between depression and obesity were unknown. Difference in biological vulnerability between male and female was one of the possible clarifications to state that sex differential association between obesity and MDD. Sex hormones were also reported to have direct link with depressed mood in women.[35,36]

In our study, serum cholesterol concentration showed increasing trend depending on the type of psychiatric disorders. Serum cholesterol concentration was lowest in psychosis followed by anxiety and then by mood disorder. However, in all types the serum cholesterol concentration were below the desirable limit as per Adult Treatment Panel III Classification (i.e. $<200 \mathrm{mg} / \mathrm{dL}$ ).[37] Total serum cholesterol is a peripheral biomarker in diagnosis and monitoring of psychiatric disorders. ${ }^{[38]}$ It was commonly observed that in patients suffering from MDD, there was decreased total cholesterol when compared to healthy controls.[39,40] Studies also claimed a lack of significant association between low serum cholesterol and depression in elderly cohorts.[41] Other study documented increased serum cholesterol levels in patients with other anxiety disorders. ${ }^{[42]}$ Many observational studies (including cohort, case-control and cross-sectional studies) and meta-analyses supported a significant relationship between low-serum cholesterol or intake of cholesterol lowering diet or medication, with violent behaviour and severe irritability.[43] In addition, experimental studies showed an increase in aggressive behaviour in monkeys assigned to low-cholesterol diets.[44] Increased LDL level was present in mood disorder patients followed by anxiety and psychosis. Our finding corroborating with considerable studies demonstrated that MDD patients exhibit increased LDL.[44,45] A case control study showed that depressed patients had higher circulating levels of LDL when compared to healthy controls.[46] GAD is associated with elevated LDL.[47] Other anxiety disorders are also associated with an increase in LDL and correlating with symptoms severity.[48] This indicates that the correct levels of cholesterol and LDL are important in diagnosing and preventing mood, anxiety and psychotic disorder patients and there must be an optimum range within which they should lie.

\section{CONCLUSION}

Observation of this study is psychiatric illnesses are still common in normal BMI people. They have desirable cholesterol and LDL among the disease group except LDL, which is above optimal level in mood disorder patients. Potential mechanism other than obesity in development of psychiatric illness still remains a challenge and scope of future study.

\section{ACKNOWLEDGEMENT}

We acknowledge Principal, College of Medicine and Sagore Dutta Hospital for his encouragement to us while carrying out 
the study and Dr. Diptakanta Mukherjee, Associate Professor, Department of Community Medicine, College of Medicine and Sagore Dutta Hospital for statistical analysis of the study.

\section{REFERENCES}

[1] Pickering RP, Goldstein RB, Hasin DS, et al. Temporal relationships between overweight and obesity and DSM-IV substance use, mood, and anxiety disorders: results from a prospective study, the National Epidemiologic Survey on Alcohol and Related Conditions. J Clin Psychiatry 2011;72(11):1494-502.

[2] PsycNET Record Display - PsycNET

[3] Moore ME, Stunkard A, Srole L. Obesity, social class, and mental illness. JAMA 1962;181(11):962-6.

[4] Istvan J, Zavela K, Weidner G. Body weight and psychological distress in NHANES I. Int J Obes Relat Metab Disord 1992;16(12):999-1003.

[5] Hällström T, Noppa H. Obesity in women in relation to mental illness, social factors and personality traits. J Psychosom Res 1981;25(2):75-82.

[6] Ross CE. Overweight and depression. J Health Soc Behav 1994;35(1):63-79.

[7] Roberts RE, Kaplan GA, Shema SJ, et al. Are the obese at greater risk for depression? Am J Epidemiol 2000;152(2):163-70.

[8] Carpenter KM, Hasin DS, Allison DB, et al. Relationships between obesity and DSM-IV major depressive disorder, suicide ideation, and suicide attempts: results from a general population study. Am J Public Health 2000;90(2):251-7.

[9] Wadden TA, Stunkard AJ. Psychopathology and obesity. Ann N Y Acad Sci 1987;499:55-65.

[10] Friedman MA, Brownell KD. Psychological correlates of obesity: moving to the next research generation. Psychol Bull 1995;117(1):3-20.

[11] Han TS, Tijhuis MA, Lean ME, et al. Quality of life in relation to overweight and body fat distribution. Am J Public Health 1998;88(12):1814-20.

[12] Noppa H, Hällström T. Weight gain in adulthood in relation to socioeconomic factors, mental illness and personality traits: a prospective study of middle-aged women. J Psychosom Res 1981;25(2):83-9.

[13] de Wit L, Luppino F, van Straten A, et al. Depression and obesity: a meta-analysis of community-based studies. Psychiatry Res 2010;178(2):230-5.

[14] Luppino FS, de Wit LM, Bouvy PF, et al. Overweight, obesity, and depression. Arch Gen Psychiatry 2010;67(3):220-9.

[15] Rajan T, Menon V. Psychiatric disorders and obesity: a review of association studies. J Postgrad Med 2017;63(3):182-90.

[16] National Health and Nutrition Examination Survey III. Body Measurements (Anthropometry) Oct, 1988.

[17] Durnin JV, Womersley J. Body fat assessed from total body density and its estimation from skinfold thickness: measurements on 481 men and women aged from 16 to 72 years. Br J Nutr 1974;32(1):77-97.

[18] Kuriyan R, Petracchi C, Ferro-Luzzi A, et al. Validation of expedient methods for measuring body composition in Indian adults. Indian J Med Res 1998;107:37-45.

[19] Misra A, Chowbey P, Makkar BM, et al. Consensus statement for diagnosis of obesity, abdominal obesity and the metabolic syndrome for Asian Indians and recommendations for physical activity, medical and surgical management. J Assoc Physicians India 2009;57:163-70.

[20] Dudeja V, Misra A, Pandey RM, et al. BMI does not accurately predict overweight in Asian Indians in northern India. Br J Nutr 2001;86(1):105-12.

[21] Saarni SE, Saarni SI, Fogelholm M, et al. Body composition in psychotic disorders: a general population survey. Psychol Med 2009;39(5):801-10.

[22] Suvisaari JM, Saarni SI, Perälä J, et al. Metabolic syndrome among persons with schizophrenia and other psychotic disorders in a general population survey. J Clin Psychiatry 2007;68(7):1045-55.

[23] Kirkpatrick B, Miller BJ, Garcia-Rizo C, et al. Is abnormal glucose tolerance in antipsychotic-naive patients with non-affective psychosis confounded by poor health habits? Schizophr Bull 2012;38(2):280-4.

[24] Ogden CL, Carroll MD, Curtin LR, et al. Prevalence of overweight and obesity in the United States, 19992004. JAMA 2006;295(13):1549-55.

[25] Mather AA, Cox BJ, Enns MW, et al. Associations of obesity with psychiatric disorders and suicidal behaviors in a nationally representative sample. J Psychosom Res 2009;66(4):277-85.

[26] McLaren L, Beck CA, Patten SB, et al. The relationship between body mass index and mental health. A population-based study of the effects of the definition of mental health. Soc Psychiatry Psychiatr Epidemiol 2008;43(1):63-71.

[27] Becker ES, Margraf J, Türke V, et al. Obesity and mental illness in a representative sample of young women. Int J Obes Relat Metab Disord 2001;25 Suppl 1:S5-9.

[28] Scott KM, Bruffaerts R, Simon GE, et al. Obesity and mental disorders in the general population: results from the world mental health surveys. Int J Obes 2008;32(1):192-200.

[29] Scott KM, McGee MA, Wells JE, et al. Obesity and mental disorders in the adult general population. J Psychosom Res 2008;64(1):97-105.

[30] Simon GE, Von Korff M, Saunders K, et al. Association between obesity and psychiatric disorders in the US adult population. Arch Gen Psychiatry 2006;63(7):824-30.

[31] Petry NM, Barry D, Pietrzak RH, et al. Overweight and obesity are associated with psychiatric disorders: results from the national epidemiologic survey on alcohol and related conditions. Psychosom Med 2008;70(3):288-97.

[32] Barry D, Pietrzak RH, Petry NM. Gender differences in associations between body mass index and DSM-IV mood and anxiety disorders: results from the national epidemiologic survey on alcohol and related conditions. Ann Epidemiol 2008;18(6):458-66.

[33] Ma J, Xiao L. Obesity and depression in US women: results from the 2005-2006 national health and nutritional examination survey. Obesity 2010;18(2):347-53.

[34] Kuehner C. Gender differences in unipolar depression: an update of epidemiological findings and possible explanations. Acta Psychiatr Scand 2003;108(3):16374. 
[35] Bromberger JT, Schott LL, Kravitz HM, et al Longitudinal change in reproductive hormones and depressive symptoms across the menopausal transition: results from the Study of Women's Health Across the Nation (SWAN). Arch Gen Psychiatry 2010;67(6):598-607.

[36] Ryan J, Burger HG, Szoeke C, et al. A prospective study of the association between endogenous hormones and depressive symptoms in postmenopausal women. Menopause 2009;16(3):509-17.

[37] Burtis CA, Ashwood ER, Bruns DE. Tietz fundamentals of clinical chemistry. $7^{\text {th }}$ edn. Elsevier Saunders 2015. https://education.bd.com/tietz-fundamentals-ofclinical-chemistry-7th-edition.aspx

[38] Parekh A, Smeeth D, Milner Y, et al. The role of lipid biomarkers in major depression. Healthcare 2017;5(1):E5.

[39] Terao T, Iwata N, Kanazawa K, et al. Low serum cholesterol levels and depressive state in human dock visitors. Acta Psychiatr Scand 2000;101(3):231-4.

[40] Horsten M, Wamala SP, Vingerhoets A, et al. Depressive symptoms, social support, and lipid profile in healthy middle-aged women. Psychosom Med 1997;59(5):521-8.

[41] Brown SL, Salive ME, Harris TB, et al. Low cholesterol concentrations and severe depressive symptoms in elderly people. BMJ 1994;308(6940):1328-32.
[42] Peter H, Hand I, Hohagen F, et al. Serum cholesterol level comparison: control subjects, anxiety disorder patients, and obsessive-compulsive disorder patients. Can J Psychiatry 2002;47(6):557-61.

[43] Golomb BA. Cholesterol and violence: is there a connection? Ann Intern Med 1998;128(6):478-87.

[44] Kaplan JR, Shively CA, Fontenot MB, et al. Demonstration of an association among dietary cholesterol, central serotonergic activity, and social behavior in monkeys. Psychosom Med 1994;56(6):479-84.

[45] Olusi SO, Fido AA. Serum lipid concentrations in patients with major depressive disorder. Biol Psychiatry 1996;40(11):1128-31.

[46] Sadeghi M, Roohafza H, Afshar H, et al. Relationship between depression and apolipoproteins A and B: a case-control study. Clinics (Sao Paulo) 2011;66(1):113-7.

[47] Roohafza, H, Sadeghi, M, Afshar H, et al. Evaluation of lipid profile in patient with major depressive disorder and generalized anxiety disorder. ARYA Atherosclerosis 2005;1(1):15-18.

[48] Agargun MY, Dulger H, Inci, R, et al. Serum lipid concentrations in obsessive-compulsive disorder patients with and without panic attacks. Can J Psychiatry 2004;49(11):776-8. 